\title{
Public Relations
}

National Cancer Institute

\section{Source}

National Cancer Institute. Public Relations. NCI Thesaurus. Code C17042.

Internal and external communication to inform or influence specific publics using writing, marketing, advertising, publicity, promotions, and special events. 